\title{
Publisher's Note to: Volume 2 of Bandung: Journal of the Global South
}

Springer

Correspondence:

editorial@bandungjournal.com

Springer-Verlag, GmbH,

Tiergartenstr. 17, Heidelberg 69121,

Germany
Due to a technical mishap the publication of Bandung: Journal of the Global South started with volume 2 ; there will be no volume 1 .

The publisher apologizes for the inconvenience caused.

Received: 17 April 2015 Accepted: 17 April 2015

Published online: 13 May 2015
Submit your manuscript to a SpringerOpen ${ }^{\circ}$ journal and benefit from:

- Convenient online submission

- Rigorous peer review

- Immediate publication on acceptance

- Open access: articles freely available online

- High visibility within the field

- Retaining the copyright to your article

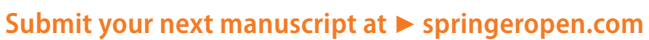

